\title{
LONG STICK EXERCISE TO REDUCE ARM AND CHEST GIRTH IN OBESE FEMALE INDIVIDUALS
}

\section{Namrata Parekh.}

B.N.Patel college of physiotherapy, Anand, Gujarat, India.

\section{ABSTRACT}

Background: Obesity in women is associated with alterations in the reproductive cycle with a reduction in fertility, as well as an increased risk of polycystic ovarian syndrome (PCOS) and infrequent or no ovulation. Overweight women with PCOS have a tendency towards insulin resistance and are prone to developing diabetes, particularly in later life. All these issues make the treatment of infertility more complicated and less successful .Furthermore the tendency toward menstrual and ovarian disturbances associated with obesity may predispose to an increased risk of ovarian, breast and endometrial cancer. In fact it is now clear the incidence of all gynaecological cancer increases with increasing BMI

Method: Fifty female aged between 20 and 60 years of age who were body mass index greater than $25 \mathrm{~kg} / \mathrm{cm}^{2}$ eligible for this study. Use of long stick 20 times repeated movements. female doing long stick exercise 25 minutes per day. During the exercise sessions, subjects were led by an instructor, and they imitated the motions and postures at the same speed. After 40 days of exercise program Arm and chest girth measured by measuring tap.

Result: The result of 50 subjects was analyzed using SPSS version 16.0. The level of significance was kept at $p<0.05$. The data was screened by mann - Whitney $U$ test. A total of 50 subjects volunteered to participated in this study.

Conclusion: For Arm girth ,Pre and post significant difference was founded. For Chest girth, Pre and post significant difference was founded.

KEY WORDS: Long stick exercise, obesity, female.

Address for correspondence: Dr. Namrata Parekh, B.N.Patel college of physiotherapy, Anand, Gujarat, India. E-Mail: parekhnamr@gmail.com

Access this Article online

Quick Response code

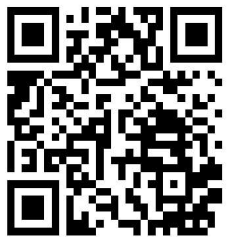

DOI: $10.16965 /$ ijpr.2019.133
Journal Information

International Journal of Physiotherapy and Research

ICV for 2016 ISSN (E) 2321-1822 | ISSN (P) 2321-8975

86.93

https://www.ijmhr.org/ijpr.html

DOI-Prefix: https://dx.doi.org/10.16965/ijpr

\section{Article Information}

Received: 24 Mar 2019

Peer Review: 25 Mar 2019

Revised: None
Accepted: 22 Apr 2019

Published (O): 11 Jun 2019

Published (P): 11 Jun 2019

\section{INTRODUCTION}

Obesity in women is associated with alterations in the reproductive cycle with a reduction in fertility, as well as an increased risk of polycystic ovarian syndrome (PCOS) and infrequent or no ovulation. Overweight women with PCOS have a tendency towards insulin resistance and are prone to developing diabetes, particularly in later life. All these issues make the treatment of infertility more complicated and less successful [1]. Furthermore the tendency toward menstrual and ovarian disturbances associated with obesity may predispose to an increased risk of ovarian, breast and endometrial cancer. In fact it is now clear the incidence of all gynaecological cancer increases with increasing BMI [2]. Maternal obesity during pregnancy is also fraught with risks to both the mother and baby. Adversematernal outcomes associated with obesity include an increased risk of spontaneous miscarriage, gestational diabetes, hypertensive disease of pregnancy including gestational 
proteinuric hypertension with multi-system consequences [3]. Pregnancy is more likely to be prolonged, while labour is more likely to be difficult requiring operative delivery which brings increased risk of infection, thrombo-embolism, and debilitation [4].

Adverse foetal outcomes associated with maternal adiposity include problems arising from iatrogenic prematurity, macrosomia (big babies) and associated birth trauma especially resulting from shoulder dystocia. Big babies have themselves a predisposition to adiposity and metabolic disorders in childhood and later life. Maternal obesity also confers an elevated risk of congenital abnormalities, particularly congenital heart disease and neural tube defects. The obese woman is also less likely to succeed in breastfeeding, requiring resort to artificial feeding which in itself increases the risk of childhood obesity. Although an elevated body mass index $[5,6]$ and central adiposity [7] are established risk factors for insulin resistance and the onset of type 2 diabetes mellitus, little is known about the contribution of extra-abdominal adipose tissue, including breast tissue, about $60 \%$ of which is fatty tissue, to this process $[8,9]$.

We hypothesized that a woman's breast size in late adolescence reflects her predisposition to insulin resistance and type 2 diabetes mellitus that is both additive to, and independent of, BMI. Although it is not known whether adipose tissue in the breast contributes to the pathogenesis of insulin resistance, posterior chest adiposity - marked by a high ratio of subscapular to triceps skinfold thickness - is positively correlated with insulin resistance and type 2 diabetes [10]. The storage of steroid hormones within breast tissue, and the behaviour of breast tissue as a paracrine and autocrine organ, including expression of insulin-like growth factor-I by mammary adipocytes, has been widely discussed in relation to breast cancer, $[11,12]$. The practice is characterized by stretching and moving all bodily parts during exercise by using a long stick of bamboo [13]. Although LSE is practiced in many areas and has potential benefits, particularly in the areas of mental health, weight management, stroke and cardiac rehabilitation [14]. Therefore, the aim of this study was to evaluate the training effects of a
LSE program on girth reduction on arm and chest in obese female individuals.

\section{MATERIALS AND METHODS}

Fifty female aged between 20 and 60 years of age who were body mass index greater than $25 \mathrm{~kg} / \mathrm{cm}^{2}$ eligible for this study. In addition, subjects had not engaged in any strength-training program or regular aerobic exercise (defined as that exceeding two times weekly) for at least three months. Exclusion criteria included angina pectoris, history of myocardial infarction, stroke, chronic obstructive pulmonary disease, uncontrolled diabetes and hypertension, neuromuscular disease, rheumatoid arthritis, spondyloarthropathy, and other major diseases. Subjects voluntarily participated in a 40 days long stick exercise program. Pre Arm and chest girth measured by measuring tape at olecranon process to $15 \mathrm{~cm}$ above for arm and at $\mathrm{T}_{4}$ level for chest. Each set of LSE included 15 different postures like shoulder flexion, extension, abduction, adduction, elbow flexion, extension, twisting waist with use of long stick 20 times repeated movements. female doing long stick exercise 25 minutes per day. During the exercise sessions, subjects were led by an instructor, and they imitated the motions and postures at the same speed. After 40 days of exercise program Arm and chest girth measured by measuring tap.

\section{RESULTS}

The result of 50 subjects was analyzed using SPSS version 16.0. The level of significance was kept at $p<0.05$. The data was screened by mann - Whitney $U$ test. A total of 50 subjects volunteered to participated in this study. For Arm girth,Pre measurement were $34.28 \pm 5.23 \mathrm{~cm}$ and Post measurement were $30.16 \pm 4.46 \mathrm{~cm}$.Significant difference was founded.(show table 1\& fig.1) For Chest girth, Pre measurement were $100 \pm 10.61 \mathrm{~cm}$ and post measurement were $95 \pm 10.43 \mathrm{~cm}$.Significant difference was founded.( show table $2 \&$ fig.2).

Table 1: Pre and post Arm girth measurement.

\begin{tabular}{|c|c|}
\hline & Mean \pm SD \\
\hline Pre & $34.28 \pm 5.23 \mathrm{~cm}$ \\
\hline Post & $30.16 \pm 4.46 \mathrm{~cm}$ \\
\hline
\end{tabular}


Graph 1: Pre and Post Arm girth measurement.

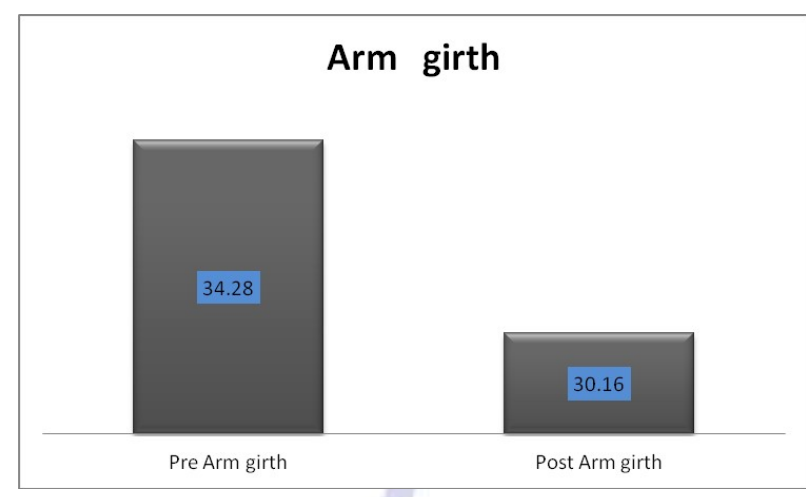

Table 2: Pre and post Chest girth measurement.

\begin{tabular}{|c|c|}
\hline & Mean \pm SD \\
\hline Pre & $100 \pm 10.61 \mathrm{~cm}$ \\
\hline Post & $95 \pm 10.43 \mathrm{~cm}$ \\
\hline
\end{tabular}

Graph 2: Pre and Post Chest girth measurement.

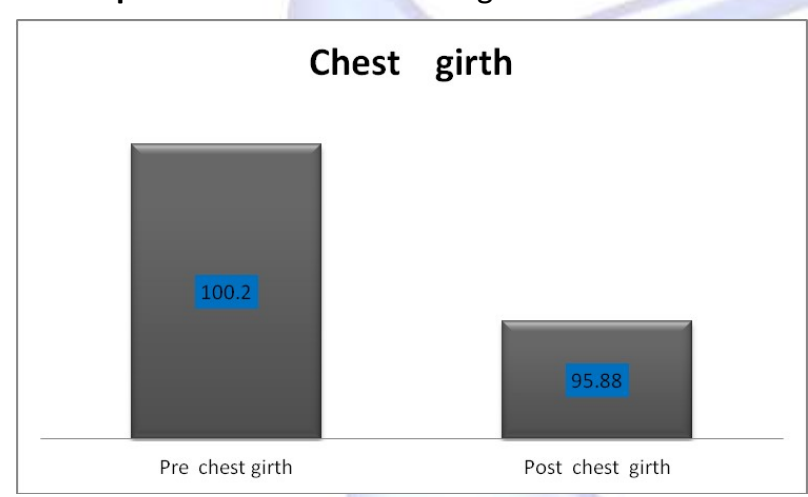

\section{DISCUSSION}

The shoulder muscles are highly solicited during stick exercise, mainly at the time of take-off and during the rotation about the shoulders to pull up on the stick. At the take-off, just after the pole is planted in the take-off box, the dominant upper arm is extended directly above the head. The stick begins to bend due to the effect of the run-up kinetic energy of the obese female. As the stick is planted, the female attempts to maintain the orientation of the arms and torso through muscular activation.

However, the ground reaction force of the stick is too great. The arms are pushed behind the shoulders and the torso behind the hips. Consequently, a part of the kinetic energy is dissipated as heat in the female's muscles and by inelastic stretching of the tendons and ligaments as the body is hyperextended [15] and more the stick is rigid, more the female must be able to resist at the reaction force of the stick [16]. Moreover, Arampatzis et al. [17] determined that additional energy is linked to the muscular work during the rotation about the shoulders, at the Maximum Bending of the stick. We hypothesised that repeatedly doing arm and chest movement continues used arm and chest muscle produced energy and burn excessive fatty tissue.

\section{CONCLUSION}

In study concluded that significantly arm and chest girth reduced with use of long stick exercise. We recommended this exercise for as a weight reduction exercise. We recommend the further study should explore the other parameters, the effects of LSE on other patients, and the risks that maybe associated with this type of exercise.

\section{Conflicts of interest: None}

\section{REFERENCES}

[1]. Sam S. Obesity and Polycystic Ovary Syndrome. Obes Manag. 2007;3:69-73.

[2]. Bhaskaran K, Douglas I, Forbes $\mathrm{H}$ et al. Body-mass index andrisk of 22 specific cancers: a population-based cohort study of $5 \cdot 24$ million UK adults. Lancet. 2014;384(9945):755-65.

[3]. Guelinckx I, Devlieger R, Beckers K et al. Maternal obesity:pregnancy complications, gestational weight gain and nutrition. Obes Rev. 2008;9:14050.

[4]. Aviram A, Hod M, Yogev Y. Maternal obesity: implications for pregnancy outcome and long-term risks - a link to maternal nutrition. Int J Gynaecol Obstet. 2011;115:S6-S10

[5]. Whitlock EP, Williams SB, Gold R, et al. Screening and interventions for childhoodoverweight: a summary of evidence for the US Preventive Services Task Force.Pediatrics 2005;116:e125-44.

[6]. Deurenberg P, Yap M. The assessment of obesity: methods for measuring body fatand global prevalence of obesity. Baillieres Best Pract Res Clin Endocrinol Metab1999;13:1-11.

[7]. Despres JP. Abdominal obesity as important component of insulin-resistance syndrome.Nutrition 1993;9:452-9.

[8]. Cruz-Korchin N, Korchin L, Gonzalez-Keelan C, et al. Macromastia: How much ofit is fat? Plast Reconstr Surg 2002;109:64-8.

[9]. Boston RC, Schnall MD, Englander SA, et al. Estimation of the content of fat andparenchyma in breast tissue using MRI T1 histograms and phantoms. Magn Resonlmaging 2005;23:591-9.

[10]. Haffner SM, Stern MP, Hazuda HP, et al. Upper body and centralized adiposity inMexican Americans and non-Hispanic whites: relation to body mass index andother behavioral and demographic variables. Int J Obes 1986;10:493-502. 
[11].Osborne CK, Coronado EB, Kitten L, et al. Insulinlike growth factor-II (IGF-II): apotential autocrine/ paracrine growth factor for human breast cancer acting via thelGF-I receptor. Mol Endocrinol 1989;3:1701-9.

[12].Rose DP, Komninou D, Stephenson GD. Obesity, adipocytokines, and insulin resistancein breast cancer. Obes Rev 2004;5:153-65.

[13]. Anonymus. The facts about Krabong. Bangkok: Siam AirCare, c2004 (In Thai). [Cited 2005 Aug 8].Available from: URL: http://www.siamaircare. com/ krabong/allframe.html

[14].Indrakamhaeng S. It's me (egotistics). 4th ed. Bangkok: Amarin Printing and Publishing, 1998b.

[15]. Linthorne, N. P. Energy loss in the pole vault take-off and the advantage of the flexible pole. Sports Engineering, 200;3(4):205-218.
[16]. Gros, H. J. and Kunkel, V. Biomechanical Analysis of the pole vault. In Scientific Research Project at the Games of the 24th Olympiad - Seoul 1988, Final Report (edited by G-P.Brüggemann and B. Glad), 1990;219-260. Monaco: International Amateur Athletics Federation.

[17]. Arampatzis, A., Schade, F. and Brüggemann, G-P. (1999). Pole Vault. In Biomechanical Research Project at the VIth World Championships in Athletics, Athens 1997: Final report (editedby G-P. Brüggemann, D. Koszewski and H. Müller), pp. 145160. Oxford: Meyer \& Meyer Sport.

How to cite this article: Namrata Parekh. LONG STICK EXERCISE TO REDUCE ARM AND CHEST GIRTH IN OBESE FEMALE INDIVIDUALS. Int J Physiother Res 2019;7(3):3104-3107. DOI: 10.16965/ijpr.2019.133 